\title{
Tianeptine Esters Derivatives: A Study of Protein-Drug Interaction Performed by Fluorescence Quenching and Molecular Docking
}

\author{
Franciela A. Soares, ${ }^{a}$ Marco A. Ceschi, ${ }^{b}$ Daniel B. Franceschini, ${ }^{a}$ Vanessa P. do Canto, ${ }^{a}$ \\ Paulo A. Netz ${ }^{*, c}$ and Leandra F. Campo ${ }^{\circledR *, b}$ \\ ${ }^{a}$ Programa de Pós-Graduação em Química, Instituto de Química, \\ Universidade Federal do Rio Grande do Sul, 91501-970 Porto Alegre-RS, Brazil \\ ${ }^{b}$ Departamento de Química Orgânica, Instituto de Química, \\ Universidade Federal do Rio Grande do Sul, 91501-970 Porto Alegre-RS, Brazil \\ 'Departamento de Físico-Química, Instituto de Química, \\ Universidade Federal do Rio Grande do Sul, 91501-970 Porto Alegre-RS, Brazil
}

\begin{abstract}
The nature of binding between bovine serum albumin (BSA) and the antidepressant tianeptine and a new series of esters derivatives were studied in this paper. The interactions with BSA were investigated by UV-Vis and fluorescence spectroscopy at three different temperatures. The fluorescence quenching experiments showed that BSA interactions with tianeptine could be dynamic while to its esters a static mechanism was observed. The results showed that tianeptine quenches the intrinsic fluorescence of BSA more efficiently than its esters due to the presence of the free acid portion. The number of binding sites determined by fluorescence spectroscopy is approximately equal to 1 indicating that there is one binding site between BSA tianeptine esters, but the presence of a second interaction site for tianeptine at higher temperatures could be not ruled out. Molecular docking calculations point out a strong affinity of tianeptine and its esters to the site IIA of protein, supporting the hypothesis of a static quenching mechanism.
\end{abstract}

Keywords: tianeptine, protein interaction, fluorescence quenching, Stern-Volmer, docking

\section{Introduction}

Tianeptine (1, Figure 1), marketed under the name Stablon, is considered an atypical antidepressant with multimodal pharmacology. ${ }^{1}$ It is atypical because the first hypothesis for its antidepressant activity involves binding to the serotonin reuptake transporter (SERT) and stimulating serotonin reuptake. ${ }^{2}$ Later, it was shown that tianeptine also modulates the glutamatergic system, showing effects on neuroplasticity in the hippocampus and amygdala. ${ }^{3,4}$ In 2014, it was shown that tianeptine interacts with the opioid receptors $\mu$ and $\delta .{ }^{5}$ Interaction with $\mu$-receptors could explain the dependence issue in high doses, ${ }^{6}$ while interaction with $\delta$-receptor could explain the antidepressant properties. $^{7}$

Tianeptine has a lateral amino acid chain that is directly associated with the pharmacological properties of the drug. ${ }^{89}$ Tianeptine interacts highly (95\%) with the plasma

*e-mail: paulo.netz@gmail.com; leandra.campo@ufrgs.br protein human serum albumin (HSA) because of the presence of the acid portion which reflects a poor volume of distribution. ${ }^{10,11}$ Although the amino acid chain can be easily modified, the only ester derivative present in the literature ${ }^{9}$ is its ethyl ester, first synthesized by French researchers.

It is known that several drugs can be detected in plasma as serum albumin-bound conjugates, as these are the most abundant multifunctional transport proteins. ${ }^{12,13}$ The interaction with these plasma proteins can lead to changes in absorption, distribution, metabolism, and excretion properties. Moreover, it can lead to attenuation of drug potency, according to the free drug principle. ${ }^{14}$ Thus, a study on the binding characteristics of tianeptine derivatives to serum albumins is of importance in the field of antidepressant drug research.

Bovine serum albumin (BSA) is frequently used as an albumin model protein because the precise architecture of its binding pockets is known from several crystallographic and nuclear magnetic resonance (NMR) spectroscopic studies. Besides that, it is $76 \%$ structurally homologous 


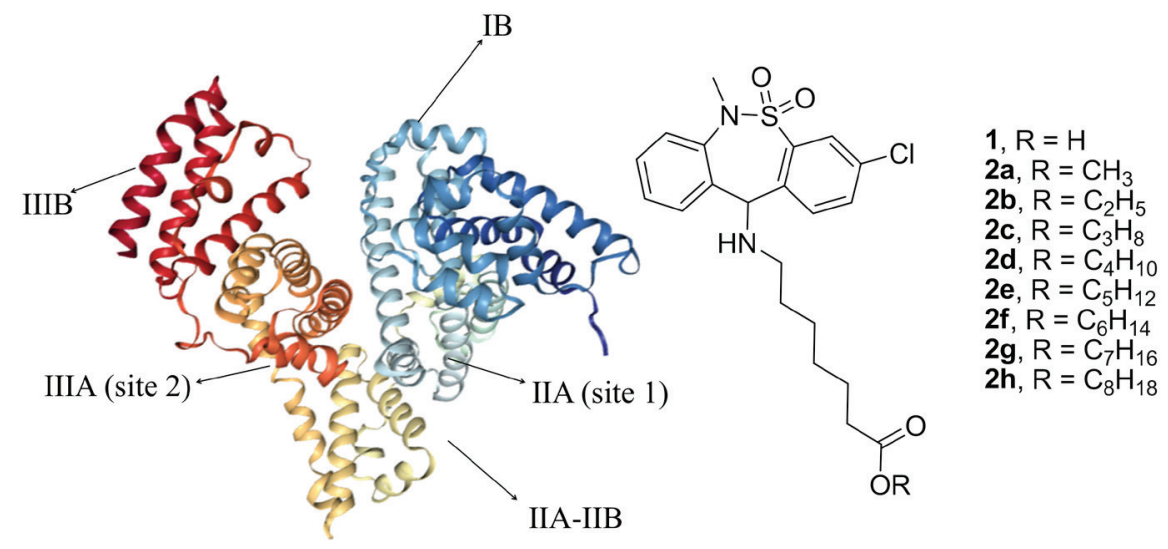

Figure 1. The overall structure of bovine serum albumin (PDB ID 4OR0) and the molecular structure of tianeptine $\mathbf{1}$ and its esters $\mathbf{2 a - h}$.

and has $75.6 \%$ of sequence identity with HSA. ${ }^{15,16}$ The intrinsic fluorescence of BSA, which is associated with two tryptophan amino acids (Trp-134 and Trp-213), is generally used for studies on the drug-protein interactions. ${ }^{17-19}$ Trp-213 is located within a hydrophobic binding pocket in subdomain IIA, and Trp-134 on the surface of the albumin molecule in domain IB, more exposed to the environment.

In the current work, we have synthesized eight esters of the antidepressant tianeptine (Figure 1), having in mind the development of new substances which are therapeutically attractive. Tianeptine and its esters absorb in the ultraviolet region but do not exhibit a significant fluorescence emission. Therefore, the intrinsic fluorescence of BSA was used to study its interactions with tianeptine and its esters to help us to clarify the drugprotein relations. These associations are very important in determining the pharmacokinetic and pharmacodynamics properties of many drugs. In order to obtain insights about the microscopic details of the interactions, molecular docking was also applied.

\section{Experimental}

\section{Materials}

Tianeptine was directly extracted from Stablon ${ }^{\circledast}$ tablets (Servier, France). The tablets were macerated and dissolved in tetrahydrofuran (THF), kept under stirring, and warmed to $50{ }^{\circ} \mathrm{C}$ for $30 \mathrm{~min}$. The solution was filtered and then concentrated on a rotary evaporator. The resulting crude product was purified by column chromatography on silica gel, using $\mathrm{CHCl}_{3}: \mathrm{MeOH}: \mathrm{NH}_{4} \mathrm{OH}$ as eluent.

Tianeptine was characterized by infrared (IR) and ${ }^{1} \mathrm{H}$ and ${ }^{13} \mathrm{C}$ NMR and the assignment of the signals was performed according to the literature. ${ }^{20}$

BSA (essentially fatty acid free) was purchased from
INLAB Brazil and its molecular weight was assumed to be $66,200 \mathrm{Da}$ in order to calculate the molar concentrations. The drug-protein solutions were prepared by mixing a solution of $\mathbf{1}$ and 2a-h and BSA in PBS (phosphate-buffered saline) buffer. To avoid precipitation of the compounds, they were previously dissolved in dimethyl sulfoxide (DMSO). BSA concentration was fixed at $5 \mu \mathrm{mol} \mathrm{L}^{-1}$, while tianeptine and tianeptine ester concentrations were varied from 0 to $25 \mu \mathrm{mol} \mathrm{L} \mathrm{L}^{-1}$. Fluorescence quenching experiment were recorded at temperatures of 293, 303, and $313 \mathrm{~K}$. All measurements were performed in triplicate with freshly made solutions.

\section{Equipment}

Infrared spectra were recorded on a Varian 640-IR spectrometer in $\mathrm{KBr}$ disks. ${ }^{1} \mathrm{H}$ and ${ }^{13} \mathrm{C}$ NMR spectra were recorded in $\mathrm{CDCl}_{3}$ solution on a Varian VNMRS $400 \mathrm{MHz}$ spectrometer. The assignment of chemical shifts was based on standard NMR experiments $\left({ }^{1} \mathrm{H}\right.$; ${ }^{13} \mathrm{C}$-APT (attached proton test); ${ }^{1} \mathrm{H},{ }^{1} \mathrm{H}-\mathrm{COSY}$ (correlation spectroscopy); ${ }^{1} \mathrm{H},{ }^{13} \mathrm{C}-\mathrm{HMQC}$ (heteronuclear multiple quantum correlation)). Chemical shifts $(\delta)$ are given in parts per million from the signal of tetramethylsilane $(\delta=0.00 \mathrm{ppm})$ as internal standard in ${ }^{1} \mathrm{H}$ NMR or from the solvent signal of $\mathrm{CDCl}_{3}(\delta=77.00 \mathrm{ppm})$ in ${ }^{13} \mathrm{C} \mathrm{NMR}$. Multiplicities are given as s (singlet), d (doublet), dd (double doublet), $\mathrm{t}$ (triplet), q (quartet), m (multiplet) or br (broad); coupling constants $(J)$ are given in $\mathrm{Hz}$. Purification by column chromatography was carried out on silica gel 60 (70-230 mesh). Analytical thin layer chromatography (TLC) was performed on aluminium plates with $0.2 \mathrm{~mm}$ of silica gel 60F-254 (Macherey-Nagel). The absorption spectra in the UV-visible region were obtained in a Shimadzu Spectrophotometer UV-2450PC. The fluorescence quenching spectra were recorded in the Shimadzu Spetrofluorometer RF-5301PC. 


\section{Synthesis}

General procedure for the synthesis of tianeptine esters 2a-c

Tianeptine (100 mg, $0.22 \mathrm{mmol}$ ) was added to a round bottom flask containing a magnetic bar. Then $2 \mathrm{~mL}$ of alcohol was added and $0.05 \mathrm{~mL}$ of concentrated sulfuric acid was dropped into the solution. The reaction mixture was refluxed for $1 \mathrm{~h}$, then cooled to room temperature and the alcohol was removed under vacuum. The yellowish oil was diluted in ethyl acetate $(5 \mathrm{~mL})$, washed with $\mathrm{Na}_{2} \mathrm{CO}_{3}$ $10 \%(5 \mathrm{~mL})$, extracted with water $(3 \times 5 \mathrm{~mL})$, and dried over $\mathrm{Na}_{2} \mathrm{SO}_{4}$. The crude product was purified by column chromatography using a mixture of hexane and ethyl acetate as eluent to give a yellowish oil.

Methyl 7-((3-chloro-6-methyl-5,5-dioxido-6,11-dihydrodibenzo[ $c, f][1,2]$ thiazepin-11-yl)amino)heptanoate (2a)

Yellowish oil ( $80 \%$ yield); UV (MeOH) $\lambda / \mathrm{nm} 210$; IR $(\mathrm{KBr}) v / \mathrm{cm}^{-1} 3340,3064,2932,2856,1736,1587,1471$, $1335,1150,581 ;{ }^{1} \mathrm{H}$ NMR $\left(400.1 \mathrm{MHz}, \mathrm{CDCl}_{3}\right) \delta 1.23-1.35$ (m, 4H), 1.41-1.52 (m, 2H), 1.55-1.64 (m, 2H), 1.75 (br, $\mathrm{NH}), 2.28$ (t, 2H, J 7.4 Hz), 2.45 (t, 2H, J 7.1 Hz), 3.37 (s, $3 \mathrm{H}), 3.65(\mathrm{~s}, 3 \mathrm{H}), 5.00(\mathrm{~s}, 1 \mathrm{H}), 7.28-7.32(\mathrm{~m}, 1 \mathrm{H}), 7.33-$ $7.41(\mathrm{~m}, 3 \mathrm{H}), 7.41-7.49(\mathrm{~m}, 2 \mathrm{H}), 7.96(\mathrm{~d}, 1 \mathrm{H}, J 1.7 \mathrm{~Hz})$; ${ }^{13} \mathrm{C} \mathrm{NMR}\left(100.6 \mathrm{MHz}, \mathrm{CDCl}_{3}\right) \delta 174.1,140.2,138.5,138.4$, $136.8,134.2,132.2,131.2,130.0,129.3,128.4,128.1$, 127.9, 66.1, 51.4, 48.0, 38.6, 33.9, 29.8, 28.9, 26.9, 24.8; high-resolution mass spectrometry (HRMS) (electrospray ionization (ESI)) $\mathrm{m} / \mathrm{z}$, calcd. for $\mathrm{C}_{22} \mathrm{H}_{27} \mathrm{ClN}_{2} \mathrm{O}_{4} \mathrm{~S}[\mathrm{M}]^{+}$: 451.1458, found: 451.1449 .

Ethyl 7-((3-chloro-6-methyl-5,5-dioxido-6,11-dihydrodibenzo[ $[c, f[1,2]$ thiazepin-11-yl)amino)heptanoate (2b)

Yellowish oil (97\% yield); $\mathrm{UV}(\mathrm{MeOH}) \lambda / \mathrm{nm} 210$; IR $(\mathrm{KBr}) \mathrm{v} / \mathrm{cm}^{-1} 3343,3066,2930,2854,1731,1583,1475$, 1335, 1150, 589; ${ }^{1} \mathrm{H}$ NMR (400.1 MHz, $\left.\mathrm{CDCl}_{3}\right) \delta 1.24$ (t, 3H, J 7.2 Hz), 1.27-1.34 (m, 4H), 1.43-1.53 (m, 2H), 1.55-1.63 (m, 2H), $2.03(\mathrm{br}, \mathrm{NH}), 2.26(\mathrm{t}, 2 \mathrm{H}, J 7.6 \mathrm{~Hz})$, $2.45(\mathrm{t}, 2 \mathrm{H}, J 7.1 \mathrm{~Hz}), 3.36(\mathrm{~s}, 3 \mathrm{H}), 4.11(\mathrm{q}, 2 \mathrm{H}, J 7.2 \mathrm{~Hz})$, $5.00(\mathrm{~s}, 1 \mathrm{H}), 7.28-7.32(\mathrm{~m}, 1 \mathrm{H}), 7.33-7.40(\mathrm{~m}, 3 \mathrm{H}), 7.42-$ $7.49(\mathrm{~m}, 2 \mathrm{H}), 7.95(\mathrm{~d}, 1 \mathrm{H}, \mathrm{J} 2.0 \mathrm{~Hz}) ;{ }^{13} \mathrm{C}$ NMR $(100.6 \mathrm{MHz}$, $\left.\mathrm{CDCl}_{3}\right) \delta 173.4,140.3,138.7,138.4,136.8,134.1,132.1$, 131.1, 130.0, 129.3, 128.3, 128.1, 127.9, 66.1, 60.1, 48.0, 38.6, 34.2, 29.8, 28.9, 26.8, 24.7, 14.2; HRMS (ESI) $\mathrm{m} / \mathrm{z}$, calcd. for $\mathrm{C}_{23} \mathrm{H}_{29} \mathrm{ClN}_{2} \mathrm{O}_{4} \mathrm{~S}[\mathrm{M}]^{+}: 465.1614$, found: 465.1604 .

Propyl 7-((3-chloro-6-methyl-5,5-dioxido-6,11-dihydrodibenzo[c,f][1,2]thiazepin-11-yl)amino)heptanoate (2c)

Yellowish oil (90\% yield); UV (MeOH) $\lambda / \mathrm{nm} 210$; IR (KBr) $v / \mathrm{cm}^{-1} 3347,3066,2930,2854,1731,1583,1467$,
1335, 1154, 584; ${ }^{1} \mathrm{H} \mathrm{NMR}\left(400.1 \mathrm{MHz}, \mathrm{CDCl}_{3}\right) \delta 0.93(\mathrm{t}$, $3 \mathrm{H}, J 7.4 \mathrm{~Hz}), 1.25$ (br, NH), 1.27-1.35 (m, 4H), 1.43-1.53 (m, 2H), 1.55-1.69 (m, 4H), 2.27 (t, 2H, J 7.6 Hz), $2.45(\mathrm{t}$, $2 \mathrm{H}, J 7.2 \mathrm{~Hz}$ ), 3.37 (s, 3H), 4.01 (t, 2H, J $6.8 \mathrm{~Hz}), 5.00$ (s, $1 \mathrm{H}), 7.27-7.32(\mathrm{~m}, 1 \mathrm{H}), 7.33-7.41(\mathrm{~m}, 3 \mathrm{H}), 7.42-7.49(\mathrm{~m}$, 2H), $7.96(\mathrm{~d}, 1 \mathrm{H}, \mathrm{J} 2.0 \mathrm{~Hz}) ;{ }^{13} \mathrm{C} \mathrm{NMR}\left(100.6 \mathrm{MHz}, \mathrm{CDCl}_{3}\right)$ $\delta$ 173.7, 140.3, 138.7, 138.5, 136.9, 134.2, 132.1, 131.1, 130.0, 129.2, 128.3, 128.0, 127.9, 66.1, 65.8, 48.0, 38.6, 34.2, 29.8, 28.9, 26.8, 24.8, 21.9, 10.3; HRMS (ESI) $\mathrm{m} / z$, calcd. for $\mathrm{C}_{24} \mathrm{H}_{31} \mathrm{ClN}_{2} \mathrm{O}_{4} \mathrm{~S}[\mathrm{M}]^{+}: 479.1771$, found: 479.1760 .

General procedure for the synthesis of tianeptine esters 2d-h

Tianeptine (100 mg, $0.22 \mathrm{mmol}$ ) was added in a round bottom flask containing a magnetic bar. Then $2 \mathrm{~mL}$ of alcohol was added and $0.05 \mathrm{~mL}$ of concentrated sulfuric acid dropped into the solution. The reaction mixture was warmed at $90{ }^{\circ} \mathrm{C}$ during $3 \mathrm{~h}$, then cooled to room temperature and the alcohol was removed under vacuum. The yellowish oil was diluted in ethyl acetate $(5 \mathrm{~mL})$, washed with $\mathrm{Na}_{2} \mathrm{CO}_{3} 10 \%(5 \mathrm{~mL})$, then extracted with water $(3 \times 5 \mathrm{~mL})$ and dried over $\mathrm{Na}_{2} \mathrm{SO}_{4}$. The crude product was purified by column chromatography using a mixture of hexane and ethyl acetate as eluent to give yellowish oil.

Butyl 7-((3-chloro-6-methyl-5,5-dioxido-6,11-dihydrodibenzo[c,f][1,2]thiazepin-11-yl)amino)heptanoate (2d)

Yellowish oil (88\% yield); UV (MeOH) $\lambda / \mathrm{nm} \mathrm{210;}$ IR (KBr) v / cm ${ }^{-1} 3343,3067,2930,2854,1727,1583$, 1467, 1334, 1154, 585; ${ }^{1} \mathrm{H}$ NMR (400.1 MHz, $\mathrm{CDCl}_{3}$ ) $\delta 0.93(\mathrm{t}, 3 \mathrm{H}, J 7.3 \mathrm{~Hz}), 1.24-1.32(\mathrm{~m}, 4 \mathrm{H}), 1.32-1.42$ (m, 2H), 1.43-1.52 (m, 2H), 1.55-1.64 (m, 4H), 1.97 (br, $\mathrm{NH}), 2.26(\mathrm{t}, 2 \mathrm{H}, J 7.3 \mathrm{~Hz}), 2.46(\mathrm{t}, 2 \mathrm{H}, J 7.1 \mathrm{~Hz}), 3.37$ $(\mathrm{s}, 3 \mathrm{H}), 4.06(\mathrm{t}, 2 \mathrm{H}, J 6.6 \mathrm{~Hz}), 5.00(\mathrm{~s}, 1 \mathrm{H}), 7.27-7.32(\mathrm{~m}$, $1 \mathrm{H}), 7.33-7.41(\mathrm{~m}, 3 \mathrm{H}), 7.42-7.48(\mathrm{~m}, 2 \mathrm{H}), 7.96(\mathrm{~d}, 1 \mathrm{H}$, $J 2.0 \mathrm{~Hz}) ;{ }^{13} \mathrm{C} \mathrm{NMR}\left(100.6 \mathrm{MHz}, \mathrm{CDCl}_{3}\right) \delta 173.8,140.3$, $138.7,138.5,136.9,134.2,132.1,131.1,130.0,129.3$, 128.4, 128.1, 127.9, 66.1, 64.1, 48.0, 38.6, 34.2, 30.6, 29.8, 28.9, 26.9, 24.8, 19.1, 13.4; HRMS (ESI) $\mathrm{m} / \mathrm{z}$, calcd. for $\mathrm{C}_{25} \mathrm{H}_{33} \mathrm{ClN}_{2} \mathrm{O}_{4} \mathrm{~S}[\mathrm{M}]^{+}:$493.1928, found: 463.1919 .

Pentyl 7-((3-chloro-6-methyl-5,5-dioxido-6,11-dihydrodibenzo[c,f][1,2]thiazepin-11-yl)amino)heptanoate (2e)

Yellowish oil (82\% yield); UV (MeOH) $\lambda / \mathrm{nm} \mathrm{210;}$ IR (KBr) v / cm ${ }^{-1} 3343,3066,2934,2858,1731,1579$, $1467,1334,1154,585 ;{ }^{1} \mathrm{H}$ NMR $\left(400.1 \mathrm{MHz}, \mathrm{CDCl}_{3}\right.$ ) $\delta 0.90(\mathrm{t}, 3 \mathrm{H}, J 7.1 \mathrm{~Hz}), 1.24-1.38(\mathrm{~m}, 8 \mathrm{H}), 1.42-1.52$ (m, 2H), 1.55-1.65 (m, 4H), $1.82(\mathrm{br}, \mathrm{NH}), 2.27(\mathrm{t}, 2 \mathrm{H}$, $J 7.4 \mathrm{~Hz}), 2.46$ (t, 2H, J 7.2 Hz), 3.37 (s, 3H), $4.05(\mathrm{t}, 2 \mathrm{H}$, $J 6.8 \mathrm{~Hz}), 5.00(\mathrm{~s}, 1 \mathrm{H}), 7.27-7.32(\mathrm{~m}, 1 \mathrm{H}), 7.33-7.41(\mathrm{~m}$, $3 \mathrm{H}), 7.42-7.48(\mathrm{~m}, 2 \mathrm{H}), 7.9(\mathrm{~d}, 1 \mathrm{H}, J 2.0 \mathrm{~Hz}) ;{ }^{13} \mathrm{C} \mathrm{NMR}$ 
$\left(100.6 \mathrm{MHz}, \mathrm{CDCl}_{3}\right) \delta 173.8,140.2,138.7,138.4,136.8$, $134.2,132.1,131.1,130.0,129.3,128.3,128.1,127.9,66.1$, 64.4, 48.0, 38.6, 34.2, 29.8, 28.9, 28.3, 28.0, 26.9, 24.8, 22.3, 13.4; HRMS (ESI) $\mathrm{m} / z$, calcd. for $\mathrm{C}_{26} \mathrm{H}_{35} \mathrm{ClN}_{2} \mathrm{O}_{4} \mathrm{~S}$ $[\mathrm{M}]^{+}:$507.2084, found: 507.2084.

Hexyl 7-((3-chloro-6-methyl-5,5-dioxido-6,11-dihydrodibenzo[c,f][1,2]thiazepin-11-yl)amino)heptanoate (2f)

Yellowish oil ( $82 \%$ yield); $U V$ (MeOH) $\lambda / \mathrm{nm} 210$; IR $(\mathrm{KBr}) \mathrm{v} / \mathrm{cm}^{-1} 3339,3067,2930,2858,1731,1583,1467$, 1331, 1158, 585; ${ }^{1} \mathrm{H}$ NMR (400.1 MHz, $\mathrm{CDCl}_{3}$ ) $\delta 0.88$ (t, 3H, J 6.9 Hz), 1.23-1.38 (m, 10H), 1.43-1.52 (m, 2H), 1.55-1.65 (m, 4H), 2.00 (br, NH), 2.27 (t, 2H, J 7.4 Hz), $2.46(\mathrm{t}, 2 \mathrm{H}, J 7.1 \mathrm{~Hz}), 3.37(\mathrm{~s}, 3 \mathrm{H}), 4.05(\mathrm{t}, 2 \mathrm{H}, J 6.7 \mathrm{~Hz})$, $5.00(\mathrm{~s}, 1 \mathrm{H}), 7.27-7.32(\mathrm{~m}, 1 \mathrm{H}), 7.33-7.41(\mathrm{~m}, 3 \mathrm{H}), 7.42-$ 7.49 (m, 2H), 7.90 (d, 1H, J 2.0 Hz); ${ }^{13} \mathrm{C} \mathrm{NMR}(100.6 \mathrm{MHz}$, $\left.\mathrm{CDCl}_{3}\right) \delta 173.7,140.3,138.6,138.5,136.8,134.1,132.1$, $131.1,130.0,129.2,128.3,128.0,127.9,66.0,64.3,48.0$, 38.6, 34.2, 31.3, 29.8, 28.9, 28.5, 26.8, 25.5, 24.8, 22.4, 13.9; HRMS (ESI) $\mathrm{m} / \mathrm{z}$, calcd. for $\mathrm{C}_{27} \mathrm{H}_{37} \mathrm{ClN}_{2} \mathrm{O}_{4} \mathrm{~S}[\mathrm{M}]^{+}$: 521.2241, found: 521.2238 .

Heptyl 7-((3-chloro-6-methyl-5,5-dioxido-6,11-dihydrodibenzo[c,f][1,2]thiazepin-11-yl)amino)heptanoate (2g)

Yellowish oil (96\% yield); UV (MeOH) $\lambda / \mathrm{nm} 210$; IR $(\mathrm{KBr}) v / \mathrm{cm}^{-1} 3335,3066,2930,2854,1731,1579,1467$, 1331, 1154, 589; ${ }^{1} \mathrm{H}$ NMR (400.1 $\left.\mathrm{MHz}, \mathrm{CDCl}_{3}\right) \delta 0.88$ (t, 3H, J 6.9 Hz), 1.22-1.37 (m, 12H), 1.43-1.52 (m, 2H), 1.54-1.65 (m, 4H), 1.88 (br, NH), 2.27 (t, 2H, J 7.6 Hz), 2.46 (t, 2H, J 7.1 Hz), 3.37 (s, 3H), 4.04 (t, 2H, J $6.8 \mathrm{~Hz}), 5.00$ (s, 1H), 7.27-7.32 (m, 1H), 7.33-7.41 (m, 3H), 7.42-7.49 $(\mathrm{m}, 2 \mathrm{H}), 7.96(\mathrm{~d}, 1 \mathrm{H}, J 2.0 \mathrm{~Hz}) ;{ }^{13} \mathrm{C} \mathrm{NMR}(100.6 \mathrm{MHz}$, $\left.\mathrm{CDCl}_{3}\right) \delta 173.7,140.3,138.7,138.5,136.9,134.1,132.1$, 131.1, 129.9, 129.2, 128.3, 128.0, 127.9, 66.0, 64.3, 48.0, 38.6, 34.2, 31.6, 29.8, 28.9, 28.8, 28.6, 26.8, 25.8, 24.8, 22.5, 14.0; HRMS (ESI) $m / z$, calcd. for $\mathrm{C}_{28} \mathrm{H}_{39} \mathrm{ClN}_{2} \mathrm{O}_{4} \mathrm{~S}$ $[\mathrm{M}]^{+}:$535.2397, found: 535.2386.

Octyl 7-((3-chloro-6-methyl-5,5-dioxido-6,11-dihydrodibenzo[c,f][1,2]thiazepin-11-yl)amino)heptanoate (2h)

Yellowish oil (64\% yield); UV (MeOH) $\lambda / \mathrm{nm} 210$; IR $(\mathrm{KBr}) \mathrm{v} / \mathrm{cm}^{-1} 3339,3062,2926,2854,1731,1583,1463$, 1334, 1155, 585; ${ }^{1} \mathrm{H}$ NMR (400.1 MHz, $\left.\mathrm{CDCl}_{3}\right) \delta 0.88$ (t, 3H, J 6.9 Hz), 1.21-1.37 (m, 16H), 1.42-1.52 (m, 2H), 1.54-1.64 (m, 4H), 2.24 (br, NH), 2.27 (t, 2H, J $7.5 \mathrm{~Hz}$ ), $2.46(\mathrm{t}, 2 \mathrm{H}, J 7.1 \mathrm{~Hz}), 3.37$ (s, 3H), 4.04 (q, 2H, J 6.7 Hz), $5.00(\mathrm{~s}, 1 \mathrm{H}), 7.27-7.32(\mathrm{~m}, 1 \mathrm{H}), 7.33-7.41(\mathrm{~m}, 3 \mathrm{H}), 7.42-$ $7.48(\mathrm{~m}, 2 \mathrm{H}), 7.96(\mathrm{~d}, 1 \mathrm{H}, \mathrm{J} 2.0 \mathrm{~Hz}) ;{ }^{13} \mathrm{C} \mathrm{NMR}(100.6 \mathrm{MHz}$, $\left.\mathrm{CDCl}_{3}\right) \delta 173.8,140.3,138.6,138.5,136.8,134.2,132.1$, $131.1,130.0,129.3,128.3,128.0,127.9,66.1,64.4,48.0$, $38.6,34.2,31.7,29.8,29.1,28.9,28.6,26.9,25.6,24.8$,
22.6, 14.0; HRMS (ESI) $m / z$, calcd. for $\mathrm{C}_{28} \mathrm{H}_{39} \mathrm{ClN}_{2} \mathrm{O}_{4} \mathrm{~S}$ $[\mathrm{M}]^{+}:$549.2554, found: 549.2539.

Molecular docking

The structures of tianeptine and esters $\mathbf{2} \mathbf{a}-\mathbf{2 h}$ were built with Gauss View ${ }^{21}$ and optimized with density functional theory (DFT) B3LYP 6-311G (d,p) using Gaussian 09. ${ }^{22}$ It was used Marvin Sketch $^{23}$ to determine the $\mathrm{p} K_{\mathrm{a}}$ and the protonation pattern of the ligands. We found out that in the experimental $\mathrm{pH}$ condition (7.4), both the protonated $\left(\mathrm{NH}_{2}^{+}\right)$and the unprotonated $(\mathrm{NH})$ groups of tianeptine and its esters have significant contributions (approximately $70 \%$ protonated). The results of both sets of dockings are very similar, the docking set with the protonated ligands was shown in the text (see Results and Discussion section) and dockings with the unprotonated ligands were given in the Supplementary Information (SI, Figure S56). The receptor structure for the docking was built from the crystal structure of the BSA complexed with naproxen, obtained from the protein data bank (PDB ID 4OR0) ${ }^{24}$ dismissing the ligands, ions and water molecules and considering only the protein. The docking calculations were carried out using AutoDockVina, ${ }^{25}$ building grid boxes of size $40 \times 40 \times 40 \AA$ visually centering them with AutoDockTools ${ }^{26}$ around the tryptophane residues 134 and 213. File format conversions were also carried out using AutoDockTools. ${ }^{26}$ The chosen BSA residues protonation pattern was the default for the AutoDockTools at neutral conditions. All the dockings were made in triplicate and it was considered only the flexibility of the ligands (the receptor structure was kept rigid). For each docking run, the pose with the most negative free energy (docking score) was analyzed, regarding position and pattern of interactions. The two-dimensional mapping of interacting residues was calculated using PoseView. ${ }^{27}$

\section{Results and Discussion}

The esters 2 a-h were synthesized using Fisher's esterification method with the correspondent alcohol as the solvent. For alcohols with boiling points above $100{ }^{\circ} \mathrm{C}$, it was necessary to keep the reaction at $90{ }^{\circ} \mathrm{C}$ to avoid tianeptine decomposition. On the other hand, to keep the yields high, it was necessary to increase the reaction time to $3 \mathrm{~h}$.

From the infrared spectra of the esters $\mathbf{2 a - h}$ it was possible to observe a very intense band at ca. $1730 \mathrm{~cm}^{-1}$ which is due to the carbonyl ester, as opposed to tianeptine, which has a discrete carbonyl band in the same region. For the esters, the band due to the hydroxyl group disappears giving rise to the $-\mathrm{NH}$ group stretching at around $3300 \mathrm{~cm}^{-1}$ (data not shown). Those results are in agreement with ${ }^{1} \mathrm{H}$ 
and ${ }^{13} \mathrm{C}$-APT NMR data. The ester formation was confirmed by the change of the carbonyl chemical shift, which changed from $178.6 \mathrm{ppm}$ for tianeptine to $173.8 \mathrm{ppm}$ for the esters. Also, for all esters, a new peak near $4.0 \mathrm{ppm}$ was observed in the ${ }^{1} \mathrm{H}$ NMR, a region typical of esters signals. No changes were observed in the chemical shifts of the tianeptine core, neither in the ${ }^{1} \mathrm{H}$ nor in the ${ }^{13} \mathrm{C}$-APT NMR spectra, indicating that the esterification was the only modification made.

The fluorescence spectra of BSA were recorded in the presence of increasing amounts of tianeptine and esters 2a-h in the wavelength range of $290-450 \mathrm{~nm}$ at 293, 303, and $313 \mathrm{~K}$ in PBS buffer. The maximum wavelength in the absorption spectrum of BSA in PBS buffer $(280 \mathrm{~nm})$ was used to obtain the fluorescence emission spectrum with a maximum present at $346 \mathrm{~nm}$. As shown in Figure 2, the fluorescence intensity of BSA at $293 \mathrm{~K}$ decreased regularly with increasing concentrations of $\mathbf{1}$ and $\mathbf{2 a - h}$. The conservation of the shape and position of the emission maximum shows that the protein maintains its native form throughout the experiment. The concentration range used was limited by the solubility of the esters. Although tianeptine remains soluble at concentrations above $500 \mu \mathrm{M}$ (data shown in Figure S4, SI section), its esters precipitate at concentrations greater than $25 \mu \mathrm{M}$.
The native fluorescence of BSA, attributed mainly to Trp amino acids, is easily quenched, because Trp can donate an electron with relative ease. ${ }^{28,29}$ In spite of the intrinsic quenching in proteins, dynamic and static quenching can be interpreted with the Stern-Volmer equation (equation 1):

$\mathrm{F}_{0} / \mathrm{F}=1+\mathrm{K}_{\mathrm{Sv}}[\mathrm{Q}]=1+\mathrm{kq} \tau_{0}[\mathrm{Q}]$

where $\mathrm{F}_{0}$ and $\mathrm{F}$ are the fluorescence intensities in the absence and presence of $\mathbf{1}$ and $\mathbf{2} \mathbf{a}-\mathbf{h}$, respectively; $\mathrm{K}_{\mathrm{SV}}$ is the Stern-Volmer constant; [Q] is the concentration of quencher; $\mathrm{kq}$ is the quenching rate constant; and $\tau_{0}$ is the average lifetime of the protein without the quencher. ${ }^{30}$

Fluorescence quenching is a process that can occur by two different mechanisms (static or dynamic) and both show temperature dependence. Static quenching can occur leading to changes in the protein secondary structure or to formation of a ground-state complex. Whereas, dynamic quenching occurs due to molecular collisions in which transfer of energy or an electron happens. In dynamic quenching, the $\mathrm{K}_{\mathrm{sv}}$ constant increases with the temperature; in the static quenching, the constant decreases..$^{30,31}$

The Stern-Volmer quenching constants $\left(\mathrm{K}_{\mathrm{SV}}\right)$ obtained at three different temperatures are listed in Table 1. As shown in Figure 3, the plots showed a good linear
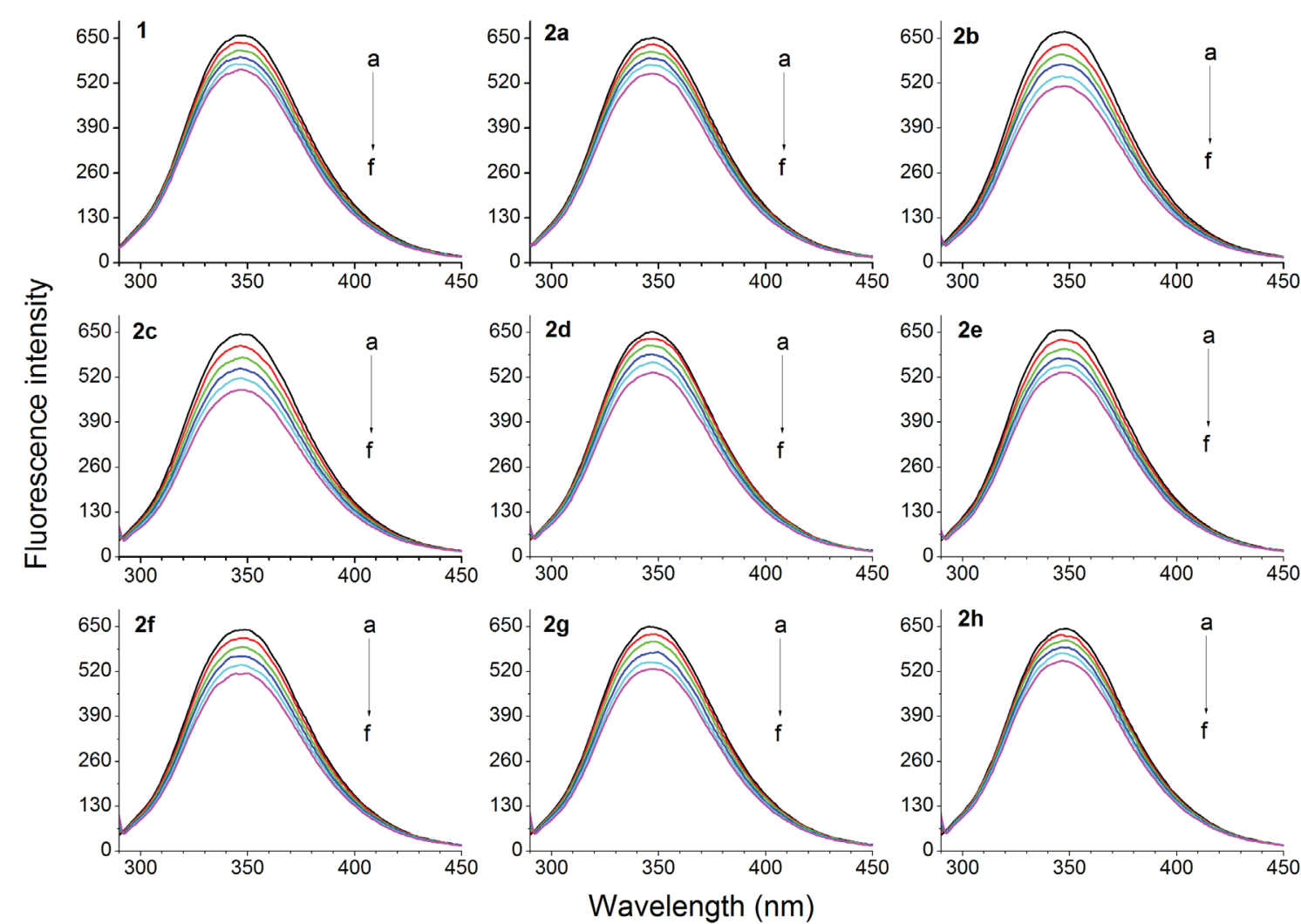

Figure 2. The effects of tianeptine $\mathbf{1}$ and esters $\mathbf{2 a}-\mathbf{h}$ on the fluorescence spectra of BSA at $293 \mathrm{~K} . \lambda_{\text {ex }}=280 \mathrm{~nm} ;[\mathrm{BSA}]=5 \mu \mathrm{mol} \mathrm{L} \mathrm{L}^{-1} ;[\mathbf{1}, \mathbf{2} \mathbf{a}-\mathbf{h}](\mu \mathrm{mol} \mathrm{L}-1)$ (a-f) $=0,5,10,15,20$ and 25 , respectively ( $\mathrm{pH}=7.4$ PBS buffer). 
relationship at every experimental temperature within the range of 0 to $25 \mu \mathrm{M}$. This indicates that only one kind of quenching mechanism is predominant, either a dynamic one or a static one. At higher concentrations (up to $25 \mu \mathrm{M}$ ), the Stern-Volmer plots for tianeptine show an upward curvature, concave towards the y-axis (Figure S4, SI section). Since the esters precipitate from the solution at concentrations above $25 \mu \mathrm{M}$, it was impossible to study the protein interaction at higher concentrations. Tianeptine has a considerable interaction with BSA which is shown from the corresponding Stern-Volmer constants $\left(\mathrm{K}_{\mathrm{SV}}\right)$ that are found to increase from $7.1 \times 10^{3} \mathrm{M}^{-1}$ at $293 \mathrm{~K}$ to $13 \times 10^{3} \mathrm{M}^{-1}$ at $313 \mathrm{~K}$, suggesting a dynamic quenching of BSA fluorescence.

For tianeptine ester derivatives, the fluorescence quenching rate of BSA at $293 \mathrm{~K}$ increases in the following order: $\mathbf{2 a} \sim \mathbf{2 h}<\mathbf{2 e}<\mathbf{2 d} \sim \mathbf{2 f}<\mathbf{2 g}<\mathbf{2 b}<\mathbf{2 c}$. Unexpectedly, the esters with smaller and larger chain size, $\mathbf{2 a}$ and $\mathbf{2 h}$, respectively, showed almost the same $\mathrm{K}_{\mathrm{SV}}$ constant at $293 \mathrm{~K}$. On the other hand, at higher temperatures, the BSA fluorescence intensity was practically unchanged in the presence of increasing amounts of the ester. This was much more pronounced for the esters with more than four carbons (data not shown). For this reason, it was critical to calculate the $\mathrm{K}_{\mathrm{SV}}$ constants for the esters at 303 and $313 \mathrm{~K}$, but from the slopes of the curves shown in Figure 3 it can be seen that $\mathrm{K}_{\mathrm{sv}}$ constants decrease with temperature. This leads us to believe that the esters $\mathbf{2 a}-\mathbf{h}$ promote a fluorescence quenching of BSA by a static mechanism.

The quenching rate constants $(\mathrm{kq})$ at different temperatures were estimated from equation 1 , considering the fluorescence life time $\left(\tau_{0}\right)$ of BSA to be equal to $10^{-8} \mathrm{~s},{ }^{32}$ and are listed in Table 1. For tianeptine, the quenching rate constant increased with increasing temperature,

Table 1. Stern-Volmer constants, binding constant, and number of binding sites parameters for BSA-tianeptine $\mathbf{1}$ and BSA-esters $\mathbf{2 a - h}$ interaction

\begin{tabular}{|c|c|c|c|c|c|c|c|}
\hline Compound & Temperature / K & $\mathrm{K}_{\mathrm{SV}} \times 10^{3} / \mathrm{M}^{-1}$ & $\mathrm{kq} \times 10^{11} /\left(\mathrm{M}^{-1} \mathrm{~s}^{-1}\right)$ & $\mathrm{R}$ & $\mathrm{K} \times 10^{4} / \mathrm{M}^{-1}$ & $\mathrm{n}$ & $\mathrm{R}$ \\
\hline & 293 & 7.1 & 7.1 & 0.997 & 0.79 & 1.01 & 0.992 \\
\hline \multirow[t]{3}{*}{1} & 303 & 12.3 & 12.3 & 0.998 & 2.29 & 1.05 & 0.995 \\
\hline & 313 & 13.0 & 13.0 & 0.981 & 218.7 & 1.48 & 0.998 \\
\hline & 293 & 7.1 & 7.1 & 0.995 & 5.88 & 1.19 & 0.998 \\
\hline \multirow[t]{3}{*}{$2 \mathbf{a}$} & 303 & 7.2 & 7.2 & 0.997 & 0.74 & 1.00 & 0.998 \\
\hline & 313 & 1.5 & 1.5 & 0.997 & 0.36 & 1.08 & 0.995 \\
\hline & 293 & 12.1 & 12.1 & 0.995 & 2.81 & 1.08 & 0.998 \\
\hline \multirow[t]{3}{*}{$2 \mathbf{b}$} & 303 & 5.2 & 5.2 & 0.999 & 0.52 & 0.99 & 0.999 \\
\hline & 313 & 4.4 & 4.4 & 0.996 & 0.14 & 0.89 & 0.999 \\
\hline & 293 & 13.8 & 13.8 & 0.995 & 5.37 & 1.13 & 0.999 \\
\hline \multirow[t]{3}{*}{$2 \mathrm{c}$} & 303 & 3.3 & 3.3 & 0.997 & 0.25 & 0.98 & 0.995 \\
\hline & 313 & 4.0 & 4.0 & 0.982 & 0.08 & 0.85 & 0.993 \\
\hline & 293 & 10.0 & 10.0 & 0.998 & 2.63 & 1.09 & 0.993 \\
\hline \multirow[t]{3}{*}{$2 d$} & 303 & 3.8 & 3.8 & 0.993 & 0.19 & 0.94 & 0.992 \\
\hline & 313 & 3.4 & 3.4 & 0.992 & 7.24 & 1.28 & 0.989 \\
\hline & 293 & 9.1 & 9.1 & 0.995 & 3.98 & 1.13 & 0.993 \\
\hline \multirow[t]{3}{*}{$2 e$} & 303 & 3.7 & 3.7 & 0.977 & 0.28 & 0.76 & 0.933 \\
\hline & 313 & 3.3 & 3.3 & 0.977 & 0.36 & 1.00 & 0.995 \\
\hline & 293 & 10.0 & 10.0 & 0.992 & 13.18 & 1.24 & 0.998 \\
\hline \multirow[t]{3}{*}{$2 f$} & 303 & 2.4 & 2.4 & 0.979 & 0.12 & 0.93 & 0.973 \\
\hline & 313 & 3.5 & 3.5 & 0.991 & 0.40 & 1.01 & 0.989 \\
\hline & 293 & 11.8 & 11.8 & 0.994 & 1.58 & 1.03 & 0.995 \\
\hline \multirow[t]{3}{*}{$2 g$} & 303 & 2.7 & 2.7 & 0.994 & 0.34 & 1.01 & 0.990 \\
\hline & 313 & 2.7 & 2.7 & 0.985 & 0.02 & 0.77 & 0.995 \\
\hline & 293 & 7.0 & 7.0 & 0.994 & 1.77 & 1.09 & 0.997 \\
\hline \multirow[t]{2}{*}{$2 h$} & 303 & 2.7 & 2.7 & 0.964 & 0.08 & 0.89 & 0.981 \\
\hline & 313 & 2.8 & 2.8 & 0.967 & 2.04 & 1.17 & 0.943 \\
\hline
\end{tabular}

$\mathrm{K}_{\mathrm{SV}}$, kq: Stern-Volmer constants; R: correlation coefficient; K: binding constant; $\mathrm{n}$ : number of binding sites. 

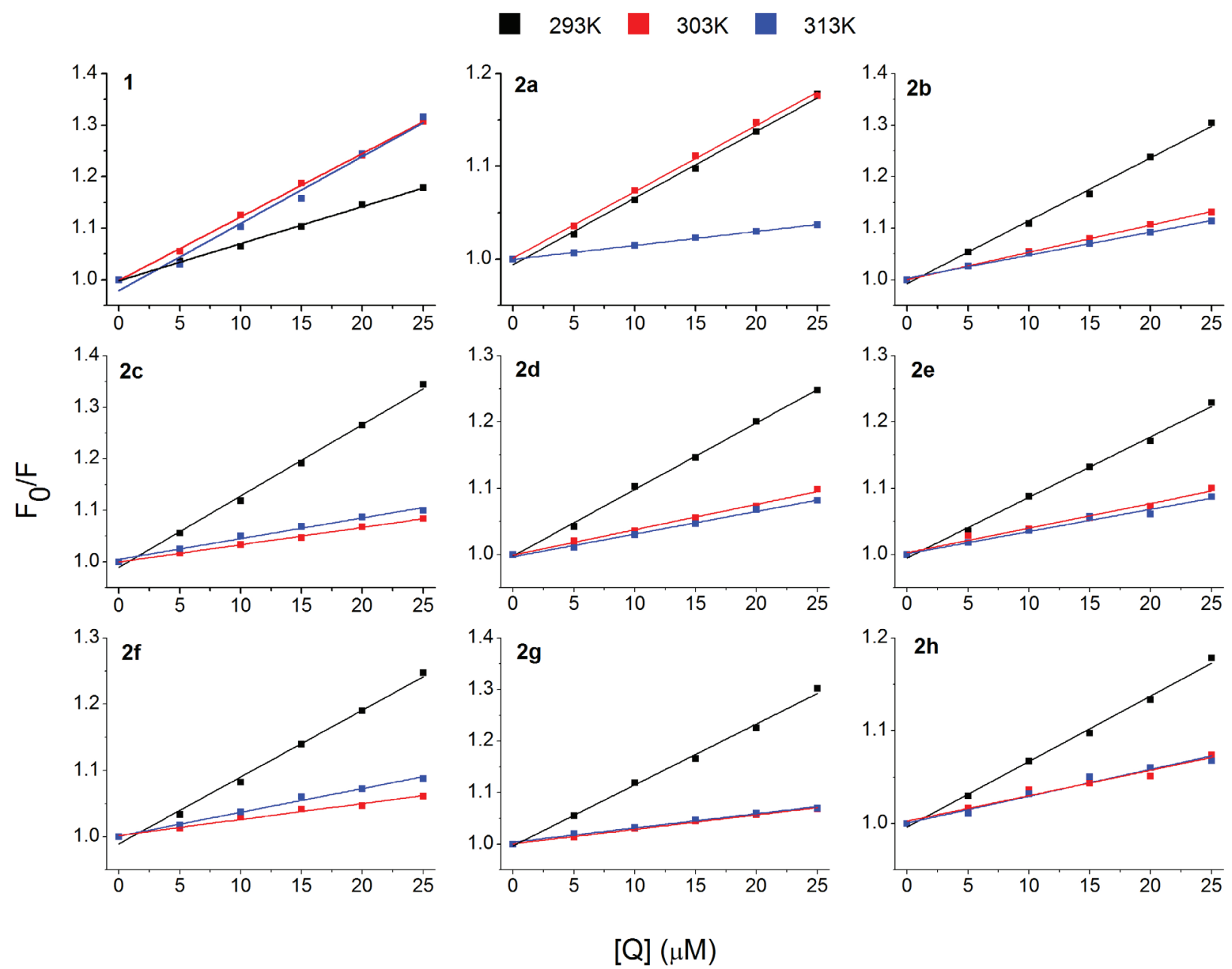

[Q] $(\mu \mathrm{M})$

Figure 3. Stern-Volmer plots of BSA quenching caused by tianeptine $\mathbf{1}$ and esters $\mathbf{2} \mathbf{a}-\mathbf{h}$ at three different temperatures. The concentrations are the same as those in Figure 2.

which indicated that the probable quenching mechanism of BSA-tianeptine interactions was initiated by dynamic collision. On the other hand, the values of $\mathrm{kq}$ for all temperatures studied were greater than the limiting diffusion rate constant of the biomolecule $\left(2.0 \times 10^{10} \mathrm{~L} \mathrm{~mol}^{-1} \mathrm{~s}^{-1}\right),{ }^{32}$ indicating that a static mechanism could be not negligible. For the esters, the kq constants were also greater than the limiting diffusion rate constant of a biomolecule, suggesting a static mechanism for fluorescence quenching of BSA, which is in agreement with the of $\mathrm{K}_{\mathrm{SV}}$ results.

To help us obtain more information about tianeptine derivatives and BSA interactions, the UV absorption spectra of tianeptine derivatives, BSA, and tianeptine derivativesBSA systems were recorded (Figure 4). Tianeptine and its esters absorb UV-visible light at the wavelengths where BSA absorbs. The absorption spectrum of tianeptine shows mainly two bands located at 276 and $284 \mathrm{~nm}$. The absorption spectra of esters 2a-h have the same shape when compared with tianeptine. The absorption spectra of tianeptine and its esters were also measured in methanol

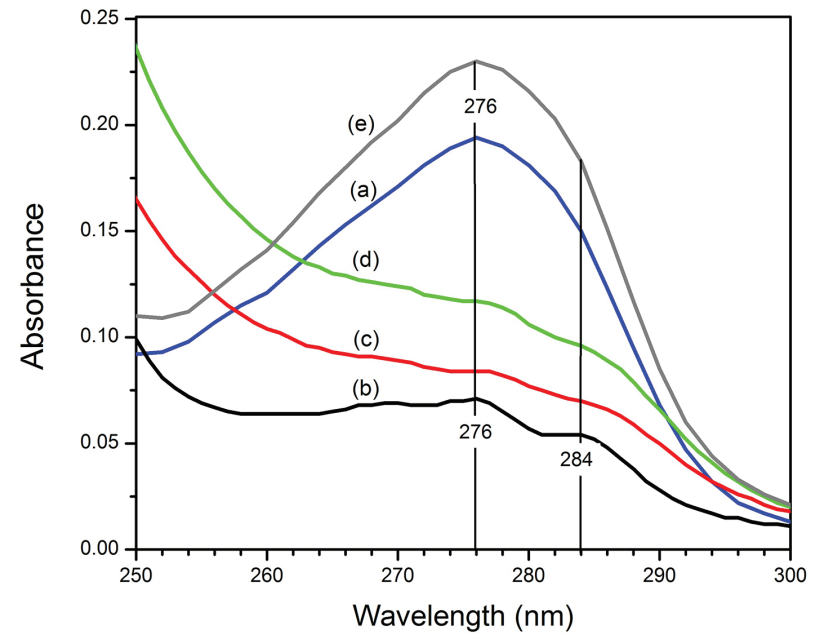

Figure 4. UV-Vis absorption spectra of (a) $[\mathrm{BSA}]=5 \mu \mathrm{mol} \mathrm{L} \mathrm{L}^{-1} \mathrm{PBS}$; (b) $[$ tianeptine $]=20 \mu \mathrm{molL}^{-1} \mathrm{PBS} / \mathrm{DMSO}$; (c) $[\mathbf{2 b}]=20 \mu \mathrm{mol} \mathrm{L}^{-1} \mathrm{PBS} / \mathrm{DMSO}$; (d) $[\mathbf{2 h}]=20 \mu \mathrm{mol} \mathrm{L}{ }^{-1}$ PBS/DMSO; (e) $[\mathrm{BSA}-2 \mathbf{b}$ complex $]=5 \mu \mathrm{mol} \mathrm{L} \mathrm{L}^{-1}$ : $20 \mu \mathrm{mol} \mathrm{L}{ }^{-1}$ PBS/DMSO. T $=298 \mathrm{~K}, \mathrm{pH}=7.4$.

and showed no significant changes relative to PBS buffer (Figure S1, SI section). The maximum signal position of the 
ester $\mathbf{2 b}$-BSA system did not change with respect to BSA, which indicated that the interaction between them does not affect the conformation nor the microenvironment of the protein. ${ }^{33}$ Therefore, protein UV absorption perturbation is not an eminent choice for probing the binding interactions of tianeptine and its esters with BSA.

From the analysis of the UV-Vis spectra, it is clear that the BSA fluorescence quenching by tianeptine derivatives does not involve a resonance energy transfer type of mechanism. According to Forster's energy transfer theory, the energy transfer from one molecule (donor) to another molecule (acceptor) will happen as long as the fluorescence emission spectrum of donor overlaps with the UV absorption spectrum of acceptor. ${ }^{34}$ From Figure 5, it is evident that the UV-Vis absorption spectra of tianeptine and ester $\mathbf{2 b}$ are completely out of the range of the fluorescence emission wavelength of BSA, which indicated that BSA fluorescence was not quenched by transferring the fluorescence resonance energy to tianeptine and its esters molecules.

The binding constant $(\mathrm{K})$ and the number of binding sites (n) were obtained from fluorescence intensity data. According to equation 2, the equilibrium established between free and bound molecules to a biomolecule takes into account the fact that small molecules bind independently to a set of sites on a protein. ${ }^{35}$

$\log \left(\frac{\left(\mathrm{F}_{0}-\mathrm{F}\right)}{\mathrm{F}}\right)=\log \mathrm{K}+\mathrm{n} \log [\mathrm{Q}]$

Figure 6 shows the double-logarithm curve $\left(\log \left[\left(\mathrm{F}_{0}-\mathrm{F}\right) / \mathrm{F}\right] v s . \log [\mathrm{Q}]\right)$ and Table 1 gives the corresponding calculated results. The number of binding sites (n) is approximately equal to 1 at all temperatures studied. This indicates that there is one binding site between BSA and the esters. On the other hand, the $\mathrm{n}$ for tianeptine increases to 1.48 when the temperature rises to $313 \mathrm{~K}$, indicating that a second binding site is being occupied. The data clearly showed that the binding sites on BSA for tianeptine and its esters were independent of temperature from 298 to $313 \mathrm{~K}$.

The determination of the binding constant by fluorescence spectroscopy is an important parameter in the protein-ligand interactions studies. Considering that the binding constants for the HSA high-affinity site ${ }^{36}$ are in the range of $8.9 \times 10^{4}-3.6 \times 10^{6} \mathrm{M}^{-1}$ we can assume that tianeptine and its esters have good affinity for BSA at $293 \mathrm{~K}$. The binding constants in this temperature increase in the following order: $\mathbf{1}<\mathbf{2 g}<\mathbf{2 h}<\mathbf{2 d}<\mathbf{2 b}<\mathbf{2} \mathrm{e}<$ $\mathbf{2} \mathbf{c}<\mathbf{2} \mathbf{a}<\mathbf{2} \mathbf{f}$ (Table 1). These results show that $\mathbf{2} \mathbf{f}$ has the strongest ability $\left(\mathrm{K}=13.18 \mathrm{M}^{-1}\right)$ to bind with $\mathrm{BSA}$, while

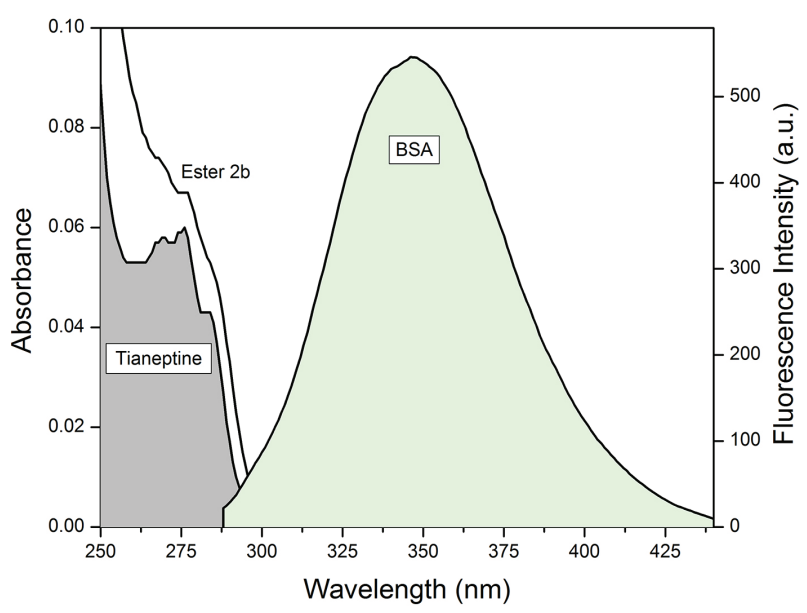

Figure 5. Overlap of the fluorescence emission spectrum of BSA $\left(\lambda_{\text {exc }}=280 \mathrm{~nm}\right)$ with the UV absorption spectrum of tianeptine. [tianeptine $]=20 \mu \mathrm{mol} \mathrm{L}-1$ PBS/DMSO, $[\mathrm{BSA}]=5 \mu \mathrm{mol} \mathrm{L}-1$ PBS. $\mathrm{pH}=7.4 ; \mathrm{T}=298 \mathrm{~K}$.

tianeptine is the weakest $\left(\mathrm{K}=0.79 \mathrm{M}^{-1}\right)$. Therefore, six carbon atoms incorporated in the ester chain probably represents a limit to the modification of chain size in the tianeptine structure for a maximum interaction. When we increased the alkyl chain to seven and eight carbons, esters $\mathbf{2 h}$ and $\mathbf{2} \mathbf{g}$, respectively, it was observed that the binding constant remained in the order of the interaction of tianeptine. Moreover, at higher temperatures this behavior is inverted and tianeptine has a higher affinity $\left(\mathrm{K} \mathrm{ca} .10^{6} \mathrm{M}^{-1}\right.$, Table 1) for the protein than its esters.

Zsila $^{37}$ has claimed that tianeptine molecules are accommodated at main binding sites located in subdomain IIIA in HSA. According to the conventional view based on Sudlow's classification, ${ }^{38,39}$ compounds that are bound in this subdomain typically contain a peripheral negative charge. Tianeptine is amphoteric with two $\mathrm{p} K_{\mathrm{a}}$ values, 4.4 (acidic) and 6.86 (basic). ${ }^{11}$ So in PBS buffer solution, this drug is in its anionic form. On the other hand, the esters of tianeptine have only one acid dissociation constant because the carboxyl group no longer exists. This can point out that the esters are accommodated at a different binding site in BSA when compared with their acid analogue tianeptine.

Molecular docking calculations, using AutoDockVina ${ }^{25}$ as discussed in the Experimental section, allowed us to identify the location of the ligands and also to map the pattern of interactions. Figure 7 shows the configurations with the highest affinity for each molecule (poses with the more negative docking score) in the vicinity of each of the tryptophan residues. The docking scores were found to be strongly negative, therefore the ligand-protein complex is stable thus supporting the hypothesis that the quenching mechanism could be static. The vicinity of Trp134 corresponds to the region IB and the vicinity of $\operatorname{Trp} 213$ 

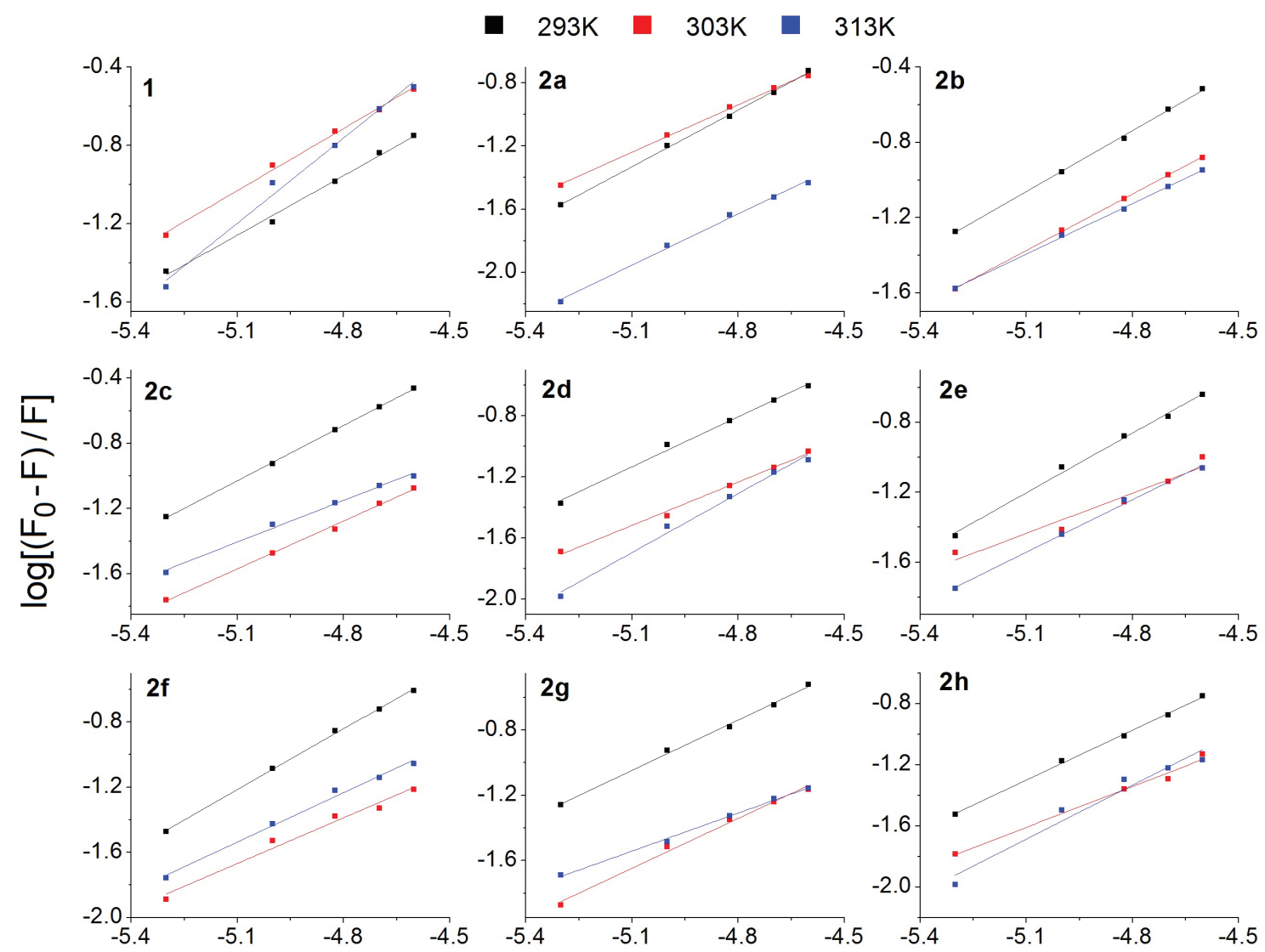

\section{$\log [Q]$}

Figure 6. The plots of $\log \left[\left(\mathrm{F}_{0}-\mathrm{F}\right) / \mathrm{F}\right]$ versus $\log [\mathrm{Q}]$ for tianeptine $\mathbf{1}$ and esters $\mathbf{2} \mathbf{a}-\mathbf{h}$ at three different temperatures. The concentrations are the same as those in Figure 2.

to region IIA, according to the classification of Sudlow. ${ }^{38}$ According to our results, the scores in the IIA region were more negative indicating a stronger affinity to residues near to Trp213 compared to Trp134. These results are similar to those found by Zhang et al. ${ }^{18}$ for the interaction of estazolam and by Shi et al. ${ }^{17}$ for the interaction of ramipril with BSA. These results point to a favorable interaction in the site IIA and help to explain the number of binding sites

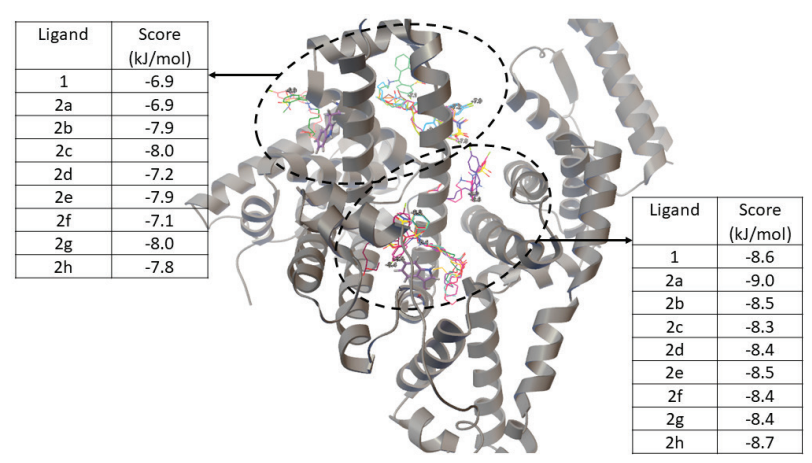

Figure 7. Best ranked docked poses for all molecules in the BSA binding site IB (above) and IIA (below). This figure shows the superposition of all ligand conformations in their best ranked poses. equal to 1 (Table 1) and they also support a predominantly static quenching mechanism, considering the high stability of the complex formed.

Figure 8 shows a detail of the interaction pattern of molecule $\mathbf{2 b}$ in the binding site IIA. Besides van der Waals

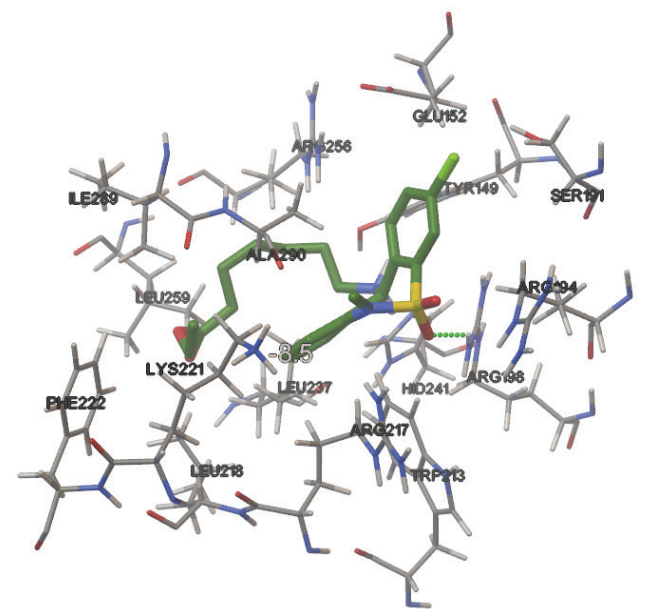

Figure 8. Residues surrounding the ester $\mathbf{2 b}$ in its best ranked docking pose in the site IIA of BSA. 
interactions with Trp213, there are noteworthy interactions with Lys221, Ala290, Leu218, Arg217, Arg194, Trp213, Leu237, Arg198, Glu152, Arg256, Tyr149, Ile289, Ser191, Leu259, Phe222 and Hid241 (protonated His residue) as well as a hydrogen bond with Arg198.

This pattern of interactions is compatible with the strong binding affinity shown in the docking score, explaining the stability of the complex and supporting the hypothesis of static quenching. We note that, contrary to the experimental results, no significant differences in the interaction sites between tianeptine and its esters were found.

\section{Conclusions}

In this work, the interactions of tianeptine and its esters with BSA were investigated by absorption and fluorescence spectroscopy and molecular docking. The experimental results showed that tianeptine quenches the intrinsic fluorescence of BSA more efficiently than its esters, due to the presence of the free acid portion. The increasing values of Stern-Volmer constants with increasing temperature indicated the presence of a dynamic quenching mechanism for tianeptine. For its esters, we observed the opposite effect: decreasing values of constants with increasing temperature. This indicated the presence of a static quenching mechanism, which was also supported by the docking results, which point out to a strong binding between BSA and the ligands. The values of $\mathrm{n}$ revealed the presence of just one binding site on BSA for tianeptine at low and moderate temperatures and for tianeptine esters in all conditions, possibly the binding site IIA (Sudlow's classification), but at higher temperatures a second interaction site for tianeptine could not be ruled out. It was possible to determine that six was the maximum number of carbons on the ester in order to achieve the best interaction with BSA.

\section{Supplementary Information}

Supplementary information $\left({ }^{1} \mathrm{H}\right.$ and ${ }^{13} \mathrm{C}$ NMR spectra, fluorescence spectra and docking calculations) is available free of charge at http://jbcs.sbq.org.br as a PDF file.

\section{Acknowledgments}

We are grateful for financial support and scholarships from the Brazilian agencies Conselho Nacional de Desenvolvimento Científico e Tecnológico (CNPq) and Coordenação de Aperfeiçoamento de Pessoal de Nível Superior (CAPES).

\section{References}

1. Bailey, S. J.; Almatroudi, A.; Kouris, A.; Curr. Psychopharmacol. 2017, 6, 94.

2. Labrid, C.; Moleyre, J.; Poignant, J. C.; Malen, C.; Mocaer, E.; Kamoun, A.; Clin. Neuropharmacol. 1988, 11, S21.

3. McEwen, B. S.; Chattarji, S.; Diamond, D. M.; Jay, T. M.; Reagan, L. P.; Svenningsson, P.; Fuchs, E.; Mol. Psychiatry 2010, 15, 237.

4. Kole, M. H.; Swan, L.; Fuchs, E.; Eur. J. Neurosci. 2002, 16, 807.

5. Gassaway, M. M.; Rives, M. L.; Kruegel, A. C.; Javitch, J. A.; Sames, D.; Transl. Psychiatry 2014, 4, 411.

6. Springer, J.; Cubala, W. J.; J. Psychoact. Drugs 2018, 50, 275.

7. Lutz, P. E.; Kieffer, B. L.; Trends Neurosci. 2013, 36, 195.

8. Laconde, G.; Depreux, P.; Berthelot, P.; Pommery, N.; Hénichart, J. P.; Eur. J. Med. Chem. 2005, 40, 167.

9. Malen, C.; Danrée, B.; Poignant, J.-C.; FR pat. 21047281971.

10. Royer, R. J.; Albin, H.; Barrucand, D.; Salvadori-Failler, C.; Kamoun, A.; Clin. Neuropharmacol. 1988, 11, 90.

11. Zini, R.; Morin, D.; Salvadori, C.; Tillement, J. P.; Br. J. Clin. Pharmacol. 1990, 29, 9.

12. Rimac, H.; Debeljak, Ž.; Bojić, M.; Miller L.; Curr. Med. Chem. 2017, 24, 1930.

13. Yang, F.; Zhang, Y.; Liang, H.; Int. J. Mol. Sci. 2014, 15, 3580.

14. Trainor, G. L.; Expert Opin. Drug Discovery 2007, 2, 21.

15. He, X. M.; Carter, D. C.; Nature 1992, 358, 209.

16. Majorek, K. A.; Porebski, P. J.; Dayal, A.; Zimmerman, M. D.; Jablonska, K.; Stewart, A. J.; Chruszcz, M.; Minor, W.; Mol. Immunol. 2012, 52, 174.

17. Shi, J. H.; Pan, D. Q.; Jiang, M.; Liu, T. T.; Wang, Q.; J. Photochem. Photobiol., B 2016, 164, 103.

18. Zhang, Y. F.; Zhou, K. L.; Lou, Y. Y.; Pan, D. Q.; Shi, J. H.; J. Biomol. Struct. Dyn. 2017, 35, 3605.

19. Carter, D. C.; Ho, J. X.; Adv. Protein Chem. 1994, 45, 153.

20. Platzer, N.; Bouchet, J. P.; Malen, C.; Labrid, C.; Mocaer, E.; Magn. Reson. Chem. 1992, 30, 1212.

21. Dennington, R.; Keith, T.; Millam, J.; GaussView, version 4.1; Semichem Inc., Shawnee Mission, USA, 2007.

22. Frisch, M. J.; Trucks, G. W.; Schlegel, H. B.; Scuseria, G. E.; Robb, M. A.; Cheeseman, J. R.; Scalmani, G.; Barone, V.; Mennucci, B.; Petersson, G. A.; Nakatsuji, H.; Caricato, M.; Li, X.; Hratchian, H. P.; Izmaylov, A. F.; Bloino, J.; Zheng, G.; Sonnenberg, J. L.; Hada, M.; Ehara, M.; Toyota, K.; Fukuda, R.; Hasegawa, J.; Ishida, M.; Nakajima, T.; Honda, Y.; Kitao, O.; Nakai, H.; Vreven, T.; Montgomery Jr., J. A.; Peralta, J. E.; Ogliaro, F.; Bearpark, M.; Heyd, J. J.; Brothers, E.; Kudin, K. N.; Staroverov, V. N.; Kobayashi, R.; Normand, J.; Raghavachari, K.; Rendell, A.; Burant, J. C.; Iyengar, S. S.; Tomasi, J.; Cossi, M.; Rega, N.; Millam, J. M.; Klene, M.; Knox, J. E.; Cross, J. B.; Bakken, V.; Adamo, C.; Jaramillo, 
J.; Gomperts, R.; Stratmann, R. E.; Yazyev, O.; Austin, A. J.; Cammi, R.; Pomelli, C.; Ochterski, J. W.; Martin, R. L.; Morokuma, K.; Zakrzewski, V. G.; Voth, G. A.; Salvador, P.; Dannenberg, J. J.; Dapprich, S.; Daniels, A. D.; Farkas, Ö.; Foresman, J. B.; Ortiz, J. V.; Cioslowski, J.; Fox, D. J.; Gaussian 09, Revision A1; Gaussian Inc., Wallingford, CT, USA, 2009.

23. MarvinSketch, version 15.12.14.0; ChemAxon, Budapest, Hungary, 2015.

24. Bujacz, A.; Zielinski, K.; Sekula, B.; Proteins 2014, 82, 2199.

25. Trott, O.; Olson, A. J.; J. Comput. Chem. 2010, 31, 455.

26. Sanner, M. F.; J. Mol. Graphics Modell. 1999, 17, 57.

27. Stierand, K.; Maaß, P. C.; Rarey, M.; Bioinformatics 2006, 22, 1710.

28. Suryawanshi, V. D.; Walekar, L. S.; Gore, A. H.; Anbhule, P. V.; Kolekar, G. B.; J. Pharm. Anal. 2016, 6, 56.

29. Callis, P. R.; J. Mol. Struct. 2014, 1077, 22.

30. Stern, O.; Volmer, M.; Phys. Z. 1919, 20, 183.
31. Paul, B. K.; Guchhait, N.; Bhattacharya, S. C.; J. Photochem. Photobiol., B 2017, 172, 11.

32. Lakowicz, J. R.; Weber, G.; Biochemistry 1973, 12, 4161.

33. Naik, P. N.; Chimatadar, S. A.; Nandibewoor, S. T.; J. Photochem. Photobiol., B 2010, 100, 147.

34. Knox, R. S.; J. Biomed. Opt. 2012, 17, 011003.

35. Lakowicz, J. R.; Principles of Fluorescence Spectroscopy, $3^{\text {rd }}$ ed.; Springer-Verlag: New York, USA, 2006.

36. Dufour, C.; Dangles, O.; Biochim. Biophys. Acta 2005, 1721, 164.

37. Zsila, F.; Mol. Pharmaceutics 2013, 10, 1668.

38. Sudlow, G.; Birkett, D. J.; Wade, D. N.; Mol. Pharmacol. 1975, 11,824 .

39. Sudlow, G.; Birkett, D. J.; Wade, D. N.; Mol. Pharmacol. 1976, 12,1052 .

Submitted: January 31, 2019

Published online: May 14, 2019 